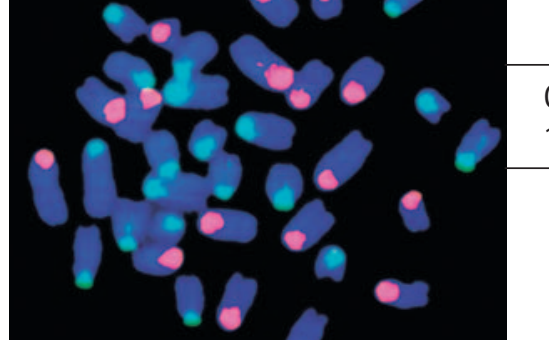

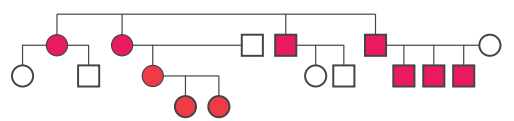
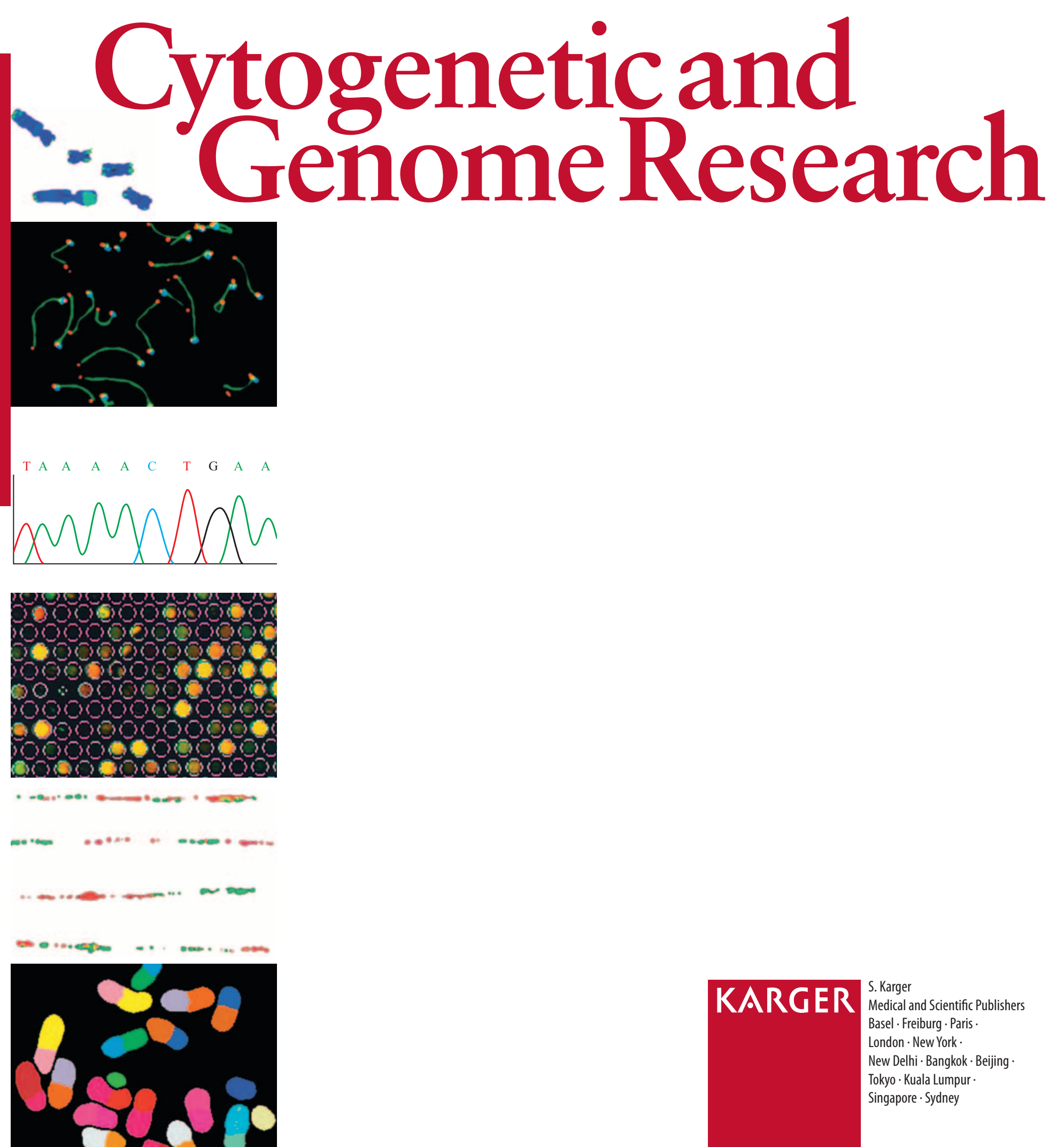


\title{
Disorders of Sex Development in Domestic Animals
}

\author{
Editors \\ Daniel A.F. Villagómez \\ Leopoldo lannuzzi \\ W. Allan King
}

The etiologies and pathologies of disorders of sex development of humans and animals explored by integrative approaches at the interface of several disciplines are relevant for fundamental biology as well as human and veterinary medicine.

This special issue of Sexual Development presents expert reviews and previously unpublished research that detail the state-of-the-art understanding of the occurrence of abnormal genetic, gonadal and phenotypic sex of livestock and wild and captive-bred exotic animals.

Providing insights into the fascinating and medically relevant causes and effects of disorders of sex development this issue is a valuable resource for researchers, clinicians as well as students of biology, animal production, agricultural sciences, human and veterinary medicine.

\section{Contents}

Preface: Villagómez, D.A.F.; lannuzzi, L. King, W.A. Molecular Mechanisms of Sexual Development: Parma, P.; Radi, 0 .

Disorders of Sexual Development and Abnormal Early Development in Domestic FoodProducing Mammals: The Role of Chromosome Abnormalities, Environment and Stress Factors: Favetta, L.A.; Villagómez, D.A.F.; lannuzzi, L.; Di Meo, G.; Webb, A.; Crain, S.; King, W.A.

Telling the Story of XX Sex Reversal in the Goat: Highlighting the Sex-Crossroad in Domestic Mammals: Pannetier, M.; Elzaiat, M.; Thépot, D.; Pailhoux, E.

Gonadal and Sex Differentiation Abnormalities of Dogs and Cats: Meyers-Wallen, V.N.

Disorders of Sexual Development in the Domestic Horse, Equus caballus: Lear, T.L.; McGee, R.B.

The Pseudoautosomal Region and Sex Chromosome Aneuploidies in Domestic Species: Raudsepp, T.; Das, P.J.; Avila, F.; Chowdhary, B.P.

Disorders of Sexual Development in Wild and Captive Exotic Animals: Mastromonaco, G.F.; Houck, M.L.; Bergfelt, D.R.

Disorders of Sexual Development in Poultry: Lambeth, L.S.; Smith, C.A.

Molecular and Cytogenetic Studies in a Case of XX SRY-Negative Sex Reversal in an Arabian Horse: Ciotola, F.; Albarella, S.; Pasolini, M.P.; Auletta, L.; Esposito, L.; Iannuzzi, L.; Peretti, $V$.

\section{KARGER}

www.karger.com/sxd

GTG Mutation in the Start Codon of the Androgen Receptor Gene in a Family of Horses with 64,XY Disorder of Sex Development: Révay, $\boldsymbol{T}$.; Villagómez, D.A.F.; Brewer, D.; Chenier, T.; King, W.A.

Cytogenetic and Molecular Characterization of $Y$ Isochromosome in a 63XO/64Xi(Yq) Mosaic Karyotype of an Intersex Horse: Das, P.J.; Lyle, S.K.; Beehan, D.; Chowdhary, B.P.; Raudsepp, $T$.

Hypospadias in a Male (78,XY; SRY-positive) Dog and Sex Reversal Female (78,XX; SRY-negative) Dogs: Clinical, Histological and Genetic Studies: Switonski, M.; Payan-Carreira, R.; Bartz, M.; Nowacka-Woszuk, J.; Szczerbal, I.; Colaço, B.; Pires, M.A.; Ochota, M.; Nizanski, W.

XX SRY-Negative True Hermaphrodism in Two Dogs: Clinical, Morphological, Genetic and Cytogenetic Studies: Groppetti, D.; Genualdo, V.; Bosi, G.; Pecile, A.; Iannuzzi, A.; Perucatti, A.; De Lorenzi, L.; Parma, P.; Arrighi, S.

Y-Autosome Translocation Interferes with Meiotic Sex Inactivation and Expression of Autosomal Genes: A Case Study in the Pig: Barasc, $\boldsymbol{H}_{\text {.; }}$ Mary, N.; Letron, R.; Calgaro, A.; Dudez, A.M.; Bonnet, N.; Lahbib-Mansais, Y.; Yerle, M.; Ducos, A.; Pinton, A.

Low Levels of X-Inactive Specific Transcript in Somatic Cell Nuclear Transfer Embryos Derived from Female Bovine Freemartin Donor Cells: Jeon, B.-G.; Rho, G.-J.; Betts, D.H.; Petrik, J.J.; Favetta, L.A.; King, W.A.

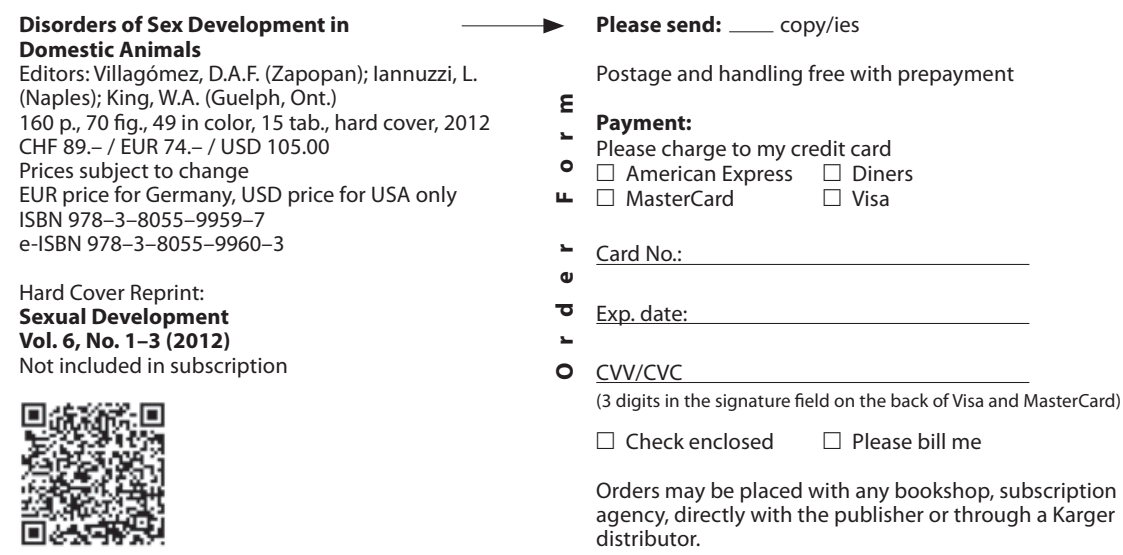

Please send:

copy/ies

Postage and handling free with prepayment

$\varepsilon$

Payment:

Please charge to my credit card

- $\square$ American Express $\square$ Diners

ᄂ $\square$ MasterCard

$\square$ Visa

Card No.

Exp. date:

CVV/CVC

(3 digits in the signature field on the back of Visa and MasterCard)

$\square$ Check enclosed $\quad \square$ Please bill me

Orders may be placed with any bookshop, subscription agency, directly with the publisher or through a Karger distributor.

Fax: +41613061234

S. Karger AG, P.O. Box, CH-4009 Basel (Switzerland)

E-Mail orders@karger.ch,www.karger.com

Name/Address: 


\section{Cytogenetic and
GenomeResearch}

Founded 1962 as 'Cytogenetics' by H.P. Klinger (1962-2004)

Changed in 1973 to 'Cytogenetics and Cell Genetics'

Changed in 2002 to 'Cytogenetic and Genome Research'

\section{Chief Editor}

\section{Michael Schmid}

Department of Human Genetics

University of Würzburg

Biozentrum, Am Hubland

D-97074 Würzburg (Germany)

Tel. (+49) 931318 4077; Fax (+49) 9313184058

E-mail: m.schmid@biozentrum.uni-wuerzburg.de

\section{Managing Editors}

Martina Guttenbach (address as for M. Schmid)

E-mail: guttenbach@biozentrum.uni-wuerzburg.de

Mechthild Krämer (address as for M. Schmid)

E-mail: mechthild.kraemer@biozentrum.uni-

wuerzburg.de

Tanja Gößwein (address as for M. Schmid)

E-mail: goesswein@biozentrum.uni-wuerzburg.de

\section{Editorial Administrator}

Claus Steinlein (address as for M. Schmid)

E-mail: claus.steinlein@biozentrum.uni-wuerzburg.de

\section{Executive Editors}

Molecular cytogenetics and molecular pathology

Linda A. Cannizzaro

Department of Pathology

Montefiore Medical Center

1635 Poplar Street

Bronx, NY 10461 (USA)

Tel. (+1) 718405 8103; Fax (+1) 7189313637

E-mail: cannizza@aecom.yu.edu

Molecular cytogenetics, gene mapping,

somatic cell genetics, informatics

Peter L. Pearson

Division of Medical Genetics, KC.04.084.2

Wilhelmina Children's Hospital

University Medical Center

P.O. Box 85090

NL-3508 AB Utrecht (The Netherlands)

Tel. (+31) 30250 3820/3815; Fax: (+31) 302505301

E-mail: p.l.pearson@med.uu.nl

\section{Editors}

Plant cytogenetics and genomics

Bernd Friebe

Department of Plant Pathology

Throckmorton Plant Sciences Center

Kansas State University

Manhattan, KS 66506-5502 (USA)

Tel. (+1) 785532 2364; Fax (+1) 7855325692

E-mail: friebe@ksu.edu

Tumor cell genetics and cancer cytogenetics

Ad Geurts Van Kessel

Department of Human Genetics

University Hospital

P.O. Box 910

NL-6500 HB Nijmegen (The Netherlands)

Tel. (+31) 24361 4107; Fax (+31) 243540488

E-mail: a.geurtsvankessel@antrg.umcn.nl

E-mail: thomas.haaf@uni-wuerzburg.de

Kent M. Reed

Department of Veterinary Pathobiology

College of Veterinary Medicine

295 Animal Science/Veterinary Medicin

1988 Fitch Avenue, University of Minnesota

St. Paul, MN 55108 (USA)

Tel. (+1) 612624 1287; Fax (+1) 6126250204

E-mail: reedx054@tc.umn.edu

Jacqueline Smith

Division of Genetics and Genomics

Roslin Institute, Roslin Midlothian

EH25 9PS (UK)

Tel. (+44) 1315274200

Fax (+44) 1314400434

E-mail: jacqueline.smith@bbsrc.ac.uk
Genes and diseases

Norma J. Nowak

New York State Center of Excellence in Bioinformatics and Life Sciences

Microarray and Genomics Facility, RPCI and

University at Buffalo

Elm and Carlton Street

Buffalo, NY 14263 (USA )

Tel. (+1) 716845 8966; Fax (+1) 7168451579

E-mail: Norma.Nowak@RoswellPark.org

Bernhard H.F. Weber

Institute of Human Genetics

University of Regensburg

Franz-Josef-Strauss-Allee 11

D-93053 Regensburg (Germany)

Tel. (+49) 941944 5400; Fax (+49) 9419445402

E-mail: bweb@klinik.uni-regensburg.de
Rando Allikmets, New York, NY

Susan E. Andrew, Edmonton, AB

Terry Ashley, New Haven, CT

Juan Pedro M. Camacho, Granada

Bhanu P. Chowdhary, College Station, TX

Andreas Dufke, Tübingen

Frederick Elder, Tampa, FL

Susanne M. Gollin, Pittsburgh, PA

Hélène Hayes, Jouy-en-Josas

Henry Heng, Detroit, MI

Neil Jones, Aberystwyth, Wales

Marcy E. MacDonald, Boston, MA

Indrajit Nanda, Würzburg

Maria Puertas, Madrid

K.H. Ramesh, Bronx, NY

Terence J. Robinson, Stellenbosch

Stephen W. Scherer, Toronto, ON

Ingo Schubert, Gatersleben

Jeremy B. Searle, Ithaca, NY

Lisa G. Shaffer, Spokane, WA

David Smith, Rochester, MN

Chandrika Sreekantaiah, Shelton, CT

Nobuo Takagi, Sapporo

Vitaly Volobouev, Paris
Printed in Switzerland on acid-free and non-aging paper (ISO 9706) by Reinhardt Druck, Basel
Appearance:

4 volumes per year (16 issues) 


\section{Cytogenetic and GenomeResearch}

\section{Cytogenetic and Genome Research}

publishes high quality original reports and reviews covering all aspects of chromosomes, genes and genomes in man, animals and plants.

Categories of publications in conventional issues Original Articles are reports on $\bullet$ Human, Animal and Plant Cytogenetics $\bullet$ Cancer Cytogenetics $\bullet \mathrm{Mo}$ lecular Cytogenetics $\bullet$ Gene Mapping, Cloning and Sequencing • Gene Characterization • Comparative Gene Mapping • Somatic Cell Genetics • Genes and Diseases - Developmental Genetics - Epigenetics. Other categories closely related to the above topics could be considered by contacting the editors.

Reviews covering a timely topic by experts in the field are either invited by the Editors or may be submitted for consideration.

Short Reports must present results of sufficient importance to justify accelerated acceptance. They should not be longer than 4 printed pages, including figures, tables and references.

Human Cytogenetics Case Reports are for de novo observations, particularly such which apply the use of HGMP (Human Genome Mapping Project) resources to the detailed characterization of chromosome rearrangements thereby further highlighting the nature of the abnormalities being described.

Cytogenetics of Rare or Endangered Species with straightforward karyotype descriptions of animals or plants should not be longer than 3 printed pages, including figures, tables and references.

Chromosome and Gene Workshops or Reports compile data that have been collected for single chromosomes, genes or genomes, hereditary diseases and gene-phenotype correlations in man, animals and plants. Illustrations and tables may be included.

Collaborative and Interactive Research Projects are contributions from investigators who are in need of research materials, or need the assistance of colleagues with specialized expertise, or who have data that is inadequate for a full report but which could be published when combined with data of others.

Commentaries are a forum for observations, opinions, and comments outside the realm of conventional scientific papers. Original data, illustrations and tables may be included.

\section{Single topic issues}

The journal has a tradition in publishing a series of themed issues. For these volumes we are soliciting the assistance of one or more expert investigators to act as Guest Editors in the area that is particularly interesting and/or one in which there is a need for a thorough overview. The Guest Editors invite top researchers to contribute original research reports or reviews of a topic that is in their main area of interest. These manuscripts are peer reviewed the same way as the papers received for the conventional issues. Proposals clearly outlining a theme and nominating potential Guest Editors are welcome.

\section{Submission}

Manuscripts should be submitted as pdf file attach ments via e-mail to m.schmid@biozentrum.uniwuerzburg.de. Authors should indicate which of the Executive or Associate Editors they feel would be most appropriate for their report. Manuscripts must be prepared strictly in accordance with the style of this journal. The first page should give the full names of the authors and their affiliations, the full postal address, telephone and fax numbers, as well as the email address of the corresponding author.

All manuscripts are subject to editorial review. The editors reserve the right to improve style and, if necessary, return the manuscript for rewriting to the authors. The editorial office reserves rights to reject manuscripts based on priorities and space availability in the journal.

\section{Arrangement}

Title page: The first page should give the full names of the authors and their affiliations, the full posta address, telephone and fax numbers, as well as the email address of the corresponding author.

Abstracts should be provided for all Original Articles, Reviews, Human Cytogenetics Case Reports, and Cytogenetics of Rare or Endangered Species.

Figures: Digital illustrations should be sharp with good contrast and color rendition. Resolution for all graphics should be at least 300 dots per inch. We request that all illustrations be in a common format such as .jpg (.jpeg .jpe), .tif (.tiff), .eps or .ppt.

Tables must be in Word format. Please us MS WORD Table > Insert > Table command from the menu bar to make tables.

\section{Literature Cited}

References should be quoted in the text as follows: single author: Jones (1999); two authors: Jones and Smith (2000); more than two authors: Jones et al (2001). The reference list should be arranged alphabetically according to the first author's surname. Titles should be given in full. Papers published in electronic format exclusively should list authors, title and journal as above followed by the journal's URL, e.g.: Chinnappan D, Zhang Y, Ravid K: AIM-1 Transgenic mice with a curly tail phenotype and its chromosome location. Cytogenet Genome Res 98:231A (2002) at: http://karger.com/doi/ 10.1159/000069799.

Book references must include the book title, editor(s), publisher, and city of publication. Recent issues of the Journal should be carefully consulted for reference list style. Agreement between text citations and the reference list should be checked carefully, and the latter checked for accuracy. If many errors are found, the manuscript will be returned for corrections which may cause considerable publication delay.

\section{Gene Symbols}

Human gene symbols: Only official gene symbols assigned by the HUGO Gene Nomenclature Committee (HGNC) are accepted. Authors must obtain or verify the official gene symbol of the gene(s) mapped and indicate that they have done so in the manuscript submitted. This can be accomplished for human genes by contacting

HUGO Gene Nomenclature Committee (HGNC)

European Bioinformatics Institute (EMBL-EBI)

Wellcome Trust Genome Campus

Hinxton, Cambridgeshire, CB10 1SA, UK

E-Mail: hgnc@genenames.org

Website: www.genenames.org
Guidelines set forth by the HUGO Gene Nomenclature Committee are available at www.genenames. org/guidelines.html

New symbols and names for genes can be requested electronically through the online gene symbol request form at http://www.genenames.org/cgi-bin/ hgnc_request.pl

Animal gene symbols: Authors submitting material on mouse and rat genetics should obtain correct genetic nomenclature before publication.

Lois Maltais

MGD Nomenclature Coordinator

The Jackson Laboratory

600 Main Street

Bar Harbour, ME 04609, USA

Tel.: +1 (207) 2886429

Fax: +1 (207) 2886132

E-Mail: nomen@informatics.jax.org

MGD home page: www.informatics.jax.org

Guidelines set forth by the International Committee on Standardized Genetic Nomenclature for Mice are available at www.informatics.jax.org/mgihome/ nomen/table.shtml; New symbols and names for genes can be requested electronically through the on-line symbol registry form at www.informatics. jax.org/mgihome/nomen

Gene mapping data for the mouse should also be submitted to the Mouse Genome Database (MGD) following the guidelines at www.informatics.jax org/mgihome/submissions/submit.shtml. The assigned MGD accession numbers should be included in the manuscript for publication. Assistance with submissions can be obtained by sending an e-mail to: submissions@informatics.jax.org

\section{Guidelines for the Use of Cell Lines}

\section{in Cancer Research}

Guidelines published by the United Kingdom Coordinating Committee on Cancer Research may be downloaded from the NCRN website at: http://www. ncrn.org.uk/csg/publications.htm

\section{Electronic Proofs}

Unless indicated otherwise, proofs are e-mailed to the corresponding author

\section{Supplementary Material}

Supplementary material is restricted to additional data that are not necessary for the scientific integrity and conclusions of the paper. Please note that all supplementary files will undergo editorial review and should be submitted together with the origina manuscript. The Editors reserve the right to limit the scope and length of the supplementary material. Supplementary material must meet production quality standards for Web publication without the need for any modification or editing. In general, supplementary files should not exceed $10 \mathrm{MB}$ in size. All figures and tables should have titles and legends and al files should be supplied separately and named clearly Acceptable files and formats are: Word or PDF files, Excel spreadsheets (only if the data cannot be converted properly to a PDF file), and video files (.mov, .avi, .mpeg)

\section{KARGER}

Fax +41 613061234 E-Mail karger@karger.ch www.karger.com 


\section{Cytogenetic and \\ GenomeResearch}

Author's Choice $^{\mathrm{TM}}$

With this option the author can choose to make his article freely available online against a one-time fee of CHF 3000.-. This fee is independent of any standard charges for supplementary pages, color images etc. which may apply. More information can be found at www.karger.com/authors_choice.

\section{Page Charges}

This journal will defray the costs of the first eight printed pages (a total of about 8,000 words minus any tables or figures). Any additional pages will have to be defrayed on a cost-sharing basis by the authors at the rate of CHF 325.- per page.

\section{Reprints}

Reprints are available against payment. Order forms listing prices are provided with the proofs. If no reprints are desired this should be indicated on the form. Orders submitted after the issue has gone to press are subject to higher prices.

There are no charges for illustrations and color reproductions.

\section{'A collection of extraordinary essays'}

\section{GOTTFRIED SCHATZ}

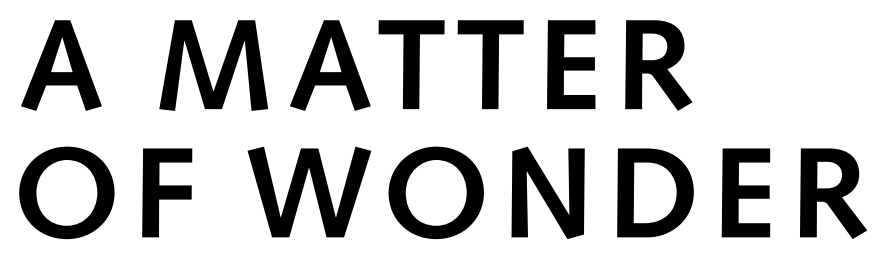

What Biology Reveals about Us, Our World, and Our Dreams

Where do we come from? Is our destiny determined by the genes we inherit? In this book Gottfried Schatz, the world-renowned biochemist and co-discoverer of mitochondrial DNA, gives lucid - albeit often surprising - answers to universal questions and takes the reader on a fascinating journey of discovery across the boundaries of scientific disciplines. With passion and a keen sense of wonder he draws on philosophy, cultural history and art to formulate his reflections on the mysteries of life. His essays will appeal not only to scientists but to all inquisitive minds, regardless of educational and professional background.

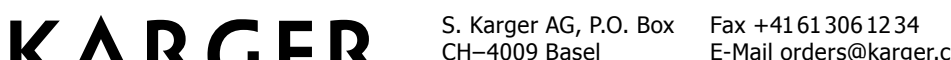 (Switzerland) www.karger.com}

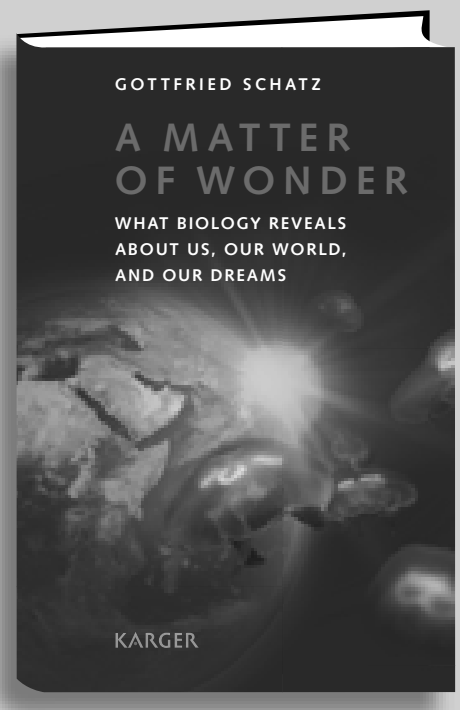

G. Schatz (Basei)

A Matter of Wonder

What Biology Reveals about Us, Our World, and Our Dreams

Translated by A. Shields

XII + 190 p., 2 color fig., hard cover, 2011

CHF 29.-/ EUR 21.50/USD 29.00

ISBN 978-3-8055-9744-9

More information and sample essays at www.karger.com/schatz

\section{KARGER}

Fax +4161306 1234

E-Mail karger@karger.ch

www.karger.com
(C) 2012 S. Karger AG, Basel

The Journal Home Page is available at: www.karger.com/cgr 


\section{Cytogenetic and Genome Research}

ISSN Print Edition: 1424-8581

ISSN Online Edition: 1424-859X

Journal Homepage: www.karger.com/cgr

Publication Data: 'Cytogenetic and Genome Research' with 4 issues, appear in 2012

Copyright: (c) 2012 S. Karger AG, Basel (Switzerland). All rights reserved. No part of this publication may be translated into other languages, reproduced or utilized in any form or by any means, electronic or mechanical, including photocopying, recording, microcopying, or by any information storage and retrieval system, without permission in writing from the publisher or, in the case of photocopying, direct payment of a specified fee to the Copyright Clearance Center.

Disclaimer: The statements, opinions and data contained in this publication are solely those of the individual authors and contributors and not of the publisher and the editor(s). The appearance of advertisements in the journal is not a warranty, endorsement, or approval of the products or services advertised or of their effectiveness, quality or safety. The publisher and the editor(s) disclaim responsibility for any injury to persons or property resulting from any ideas, methods, instructions or products referred to in the content or advertisements. is published 12 times a year. Volumes 136-138, each
Subscription Rates: Subscriptions run for a full calendar year. Prices are given per year. Personal subscription:

Print or Online

CHF 1992.-

EUR 1593-

USD 1932.00

Print+Online combined CHF 2136.-

EUR 1707.-

USD 2073.00

postage and handling (added to print and print+online)

CHF 81.60 Europe, CHF 120.- Overseas

EUR 62.40

Institutional subscription:

Print or Online

Print+Online combined

CHF 3981.

EUR 3186.-

CHF 4380.-

postage and handling (added to print and print+online)

CHF 102.- Europe, CHF 150.- Overseas

EUR 78.-

USD 141.00

Airmail surcharge: CHF 102.- / USD 96.00
USD 112.80
Back Volumes and Single Issues: Information on availability and prices of single print issues and print or electronic back volumes can be obtained from Customer Service at service@karger.ch.

Bibliographic Indices: This journal is regularly listed in bibliographic services, including Current Contents ${ }^{\circledR}$ and PubMed/MEDLINE.

Photocopying: This journal has been registered with the Copyright Clearance Center (CCC), as indicated by the code appearing on the first page of each article. For readers in the US, this code signals consent for copying of articles for personal or internal use, or for the personal or internal use of specific clients, provided that the stated fee is paid per copy directly to

Copyright Clearance Center Inc.

222 Rosewood Drive

Danvers, MA 01923 (USA)

A copy of the first page of the article must accompany payment. Consent does not extend to copying for general distribution, for promotion, for creating new works, or for resale. In these cases, specific written permission must be obtained from the copyright owner,

S. Karger AG, P.O. Box

CH-4009 Basel (Switzerland).
Subscription Orders:

Orders can be placed at agencies,

bookstores, directly with the Publisher

\section{S. Karger AG}

Medical and Scientific Publishers

P.O. Box

CH-4009 Basel

Switzerland

(for courier services only:

Allschwilerstrasse 10

CH-4055 Basel)

t: +4161306 11 11

f: +41613061234

e: karger@karger.ch

w: www.karger.com or further Karger offices

or representatives:

Germany

S. Karger GmbH

Postfach

79095 Freiburg

Deutschland

(Hausadresse: Wilhelmstrasse 20A

79098 Freiburg)

t: +49761452070

f: +497614520714

e: information@karger.de

w: www.karger.de

Japan

Karger Japan, Inc.

Shiba Daimon Asahi Bldg. 2F

1-2-23 Shiba Daimon

Minato-ku

Tokyo 105-0012

Japan

t: +81364356242

f: +81364356244

e: publisher@karger.jp

w: www.karger.jp
Change of Address:

Both old and new address should be sent to the subscription source.
USA

S. Karger Publishers, Inc.

26 West Avon Road

P.O. Box 529

Unionville, CT 06085

USA

Toll free: +18008285479

t: +18606757834

f: +18606757302

e: karger@snet.net

France

Librairie Médi-Sciences Sarl

36, bd de Latour-Maubourg

75007 Paris

France

t: $+33(0) 145514258$

f: $+33(0) 145560780$

e: librairie@medi-sciences.fr

w: www.medi-sciences.fr

Gulf Council Countries, Iran,

Middle East, North Africa, Turkey

Trans Middle East International

Distribution Co. Ltd.

KaSha

134 Queen Rania Al Abdullah Street Jordan Trade Center Bldg. 3rd Floor P.O. Box 2376

Amman 11953

Jordan

$\mathrm{t}: \quad+96265153467$

$\begin{array}{ll}\text { t: } & +96265153467 \\ \mathrm{f} & +96265153472\end{array}$

e: info@kasha.cc

w: www.KaShaonline.com
South East Asia, China and Taiwan Karger Regional Office (Malaysia) CEO Suite Kuala Lumpur Quill 7, 27th Floor

Jalan Stesen Sentral 5

KL Sentral

Kuala Lumpur 50470

Malaysia

t: +60327766803

f: +60327766999

e: service@karger.cn; r.chew@karger.cn

\section{Karger China}

10th Floor, Twin Towers (East)

B12 Jianguomenwai Avenue

Beijing 100022

China

t: +861051235033

f: +861051235122

e: service@karger.cn; r.chew@karger.cn

w: www.karger.cn

India, Bangladesh, Sri Lanka

Medscience India

Plot No. 17, Yusuf Sarai Market

B.L. Glass Building, 2nd Floor

Sri Aurobindo Marg

India

t: +911146029633

f: +911146029634

c: +919891052128

e: medsci.india@gmail.com
New Delhi 110016

\section{KARGER}

Fax +41 613061234

E-Mail karger@karger.ch

www.karger.com
(C) 2012 S. Karger AG, Basel

The Journal Home Page is available at:

www.karger.com/cgr 


\section{Contents}

See the journal website for contents

KARGER Basel $\bullet$ Freiburg $\cdot$ Paris $\bullet$ London $\bullet$ New York $\cdot$ New Delhi $•$ Bangkok Beijing $\cdot$ Tokyo $\cdot$ Kuala Lumpur $\cdot$ Singapore $\bullet$ Sydney 


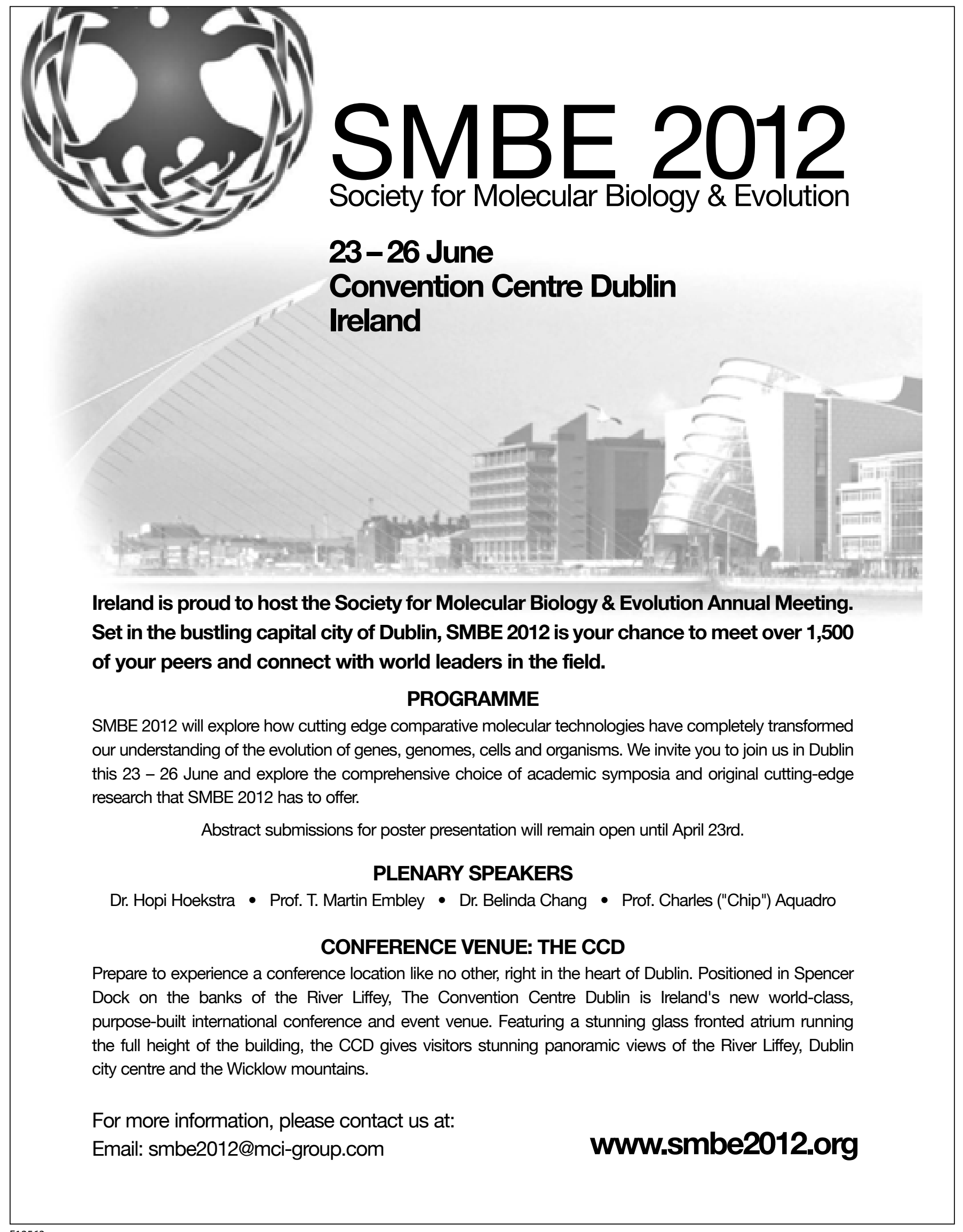




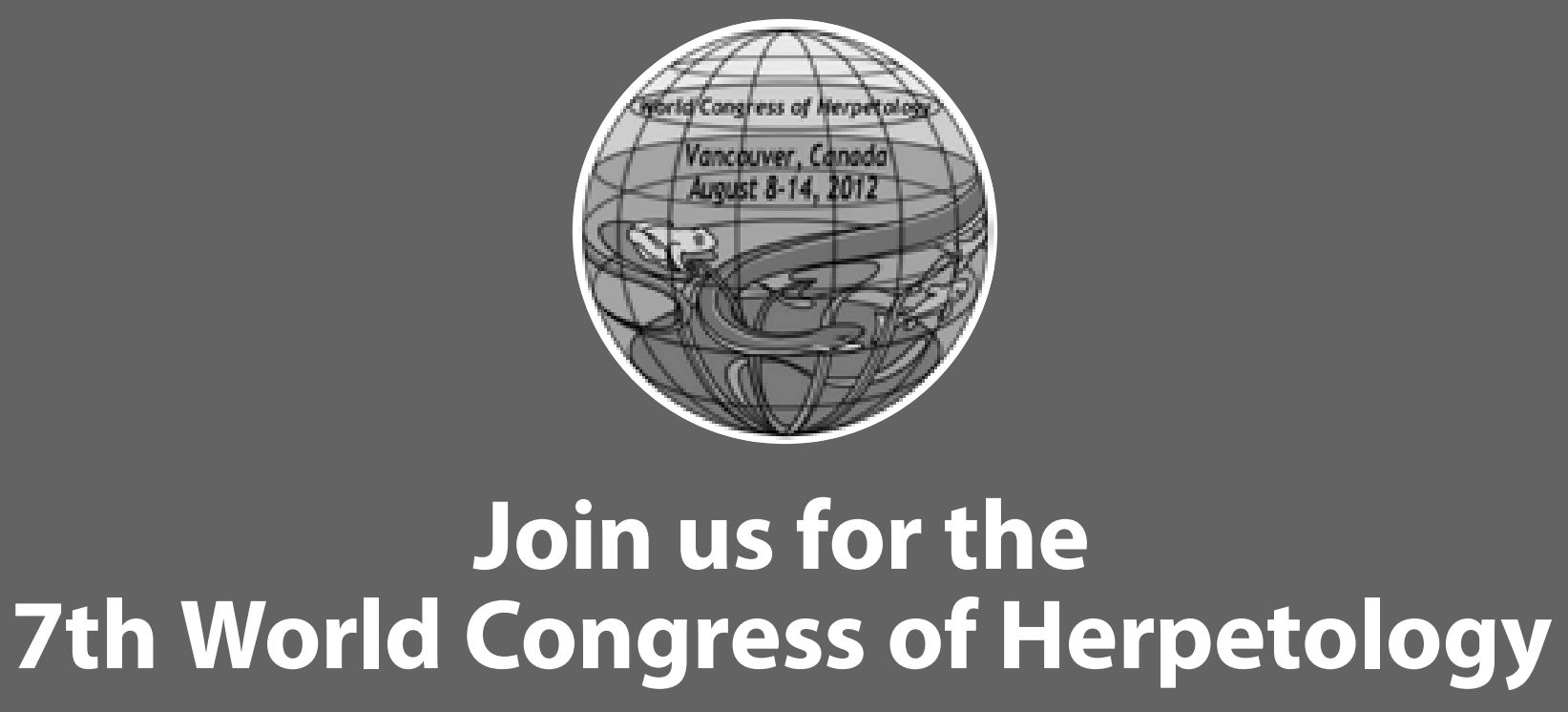

\section{University of British Columbia, Vancouver, Canada} August 8-14, 2012

WCH-7 is open to all the world's herpetologists as well as their ichthyologist colleagues.

\section{Register NOW at http://wch2012vancouver.com}

Society, committee and special interest meetings will kick off the event and exciting post congress tours will wrap up 5 full days of an eclectic and diverse scientific program.

WCH-7 will be an exceptional opportunity to meet and network with international colleagues in a stimulating and beautiful setting.

Please join us in Vancouver this summer!

\section{Call for Auction Items!}

The SSAR/HL will be hosting a silent and live auction during WCH-7. Proceeds of the live auction will benefit the World Congress of Herpetology and donations of auction items are now being solicited! For details visit the $\mathrm{WCH}-7$ website.

\section{For further information, please visit our website: http://wch2012vancouver.com}



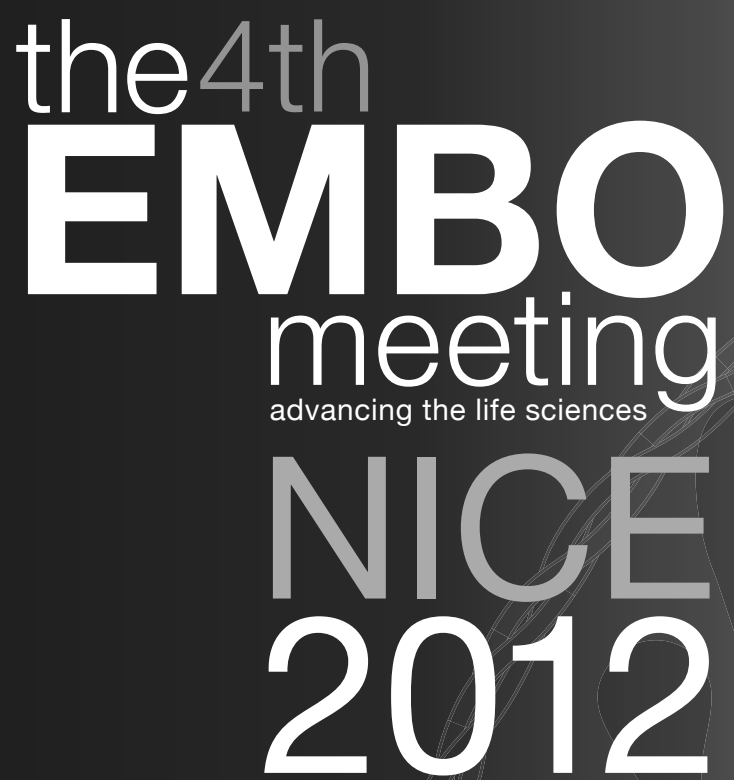

\section{2-25 September}

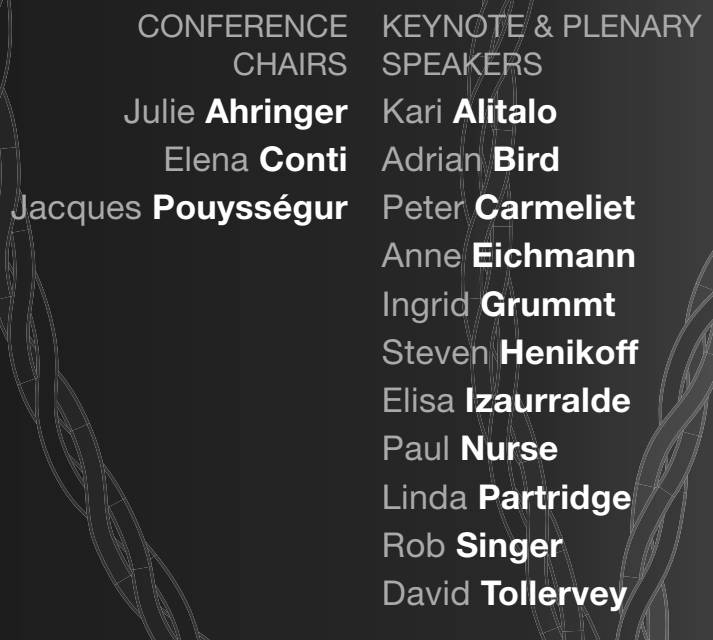

KEYNOTE \& PLENARY
SPEAKERS

Kari Alitalo

Adrian Bird

Peter Carmeliet

Anne Eichmann

Ingrid Grummt

Steven Henikoff

Elisa Izaurralde

Paul Nurse

Linda Partridge

Rob Singer

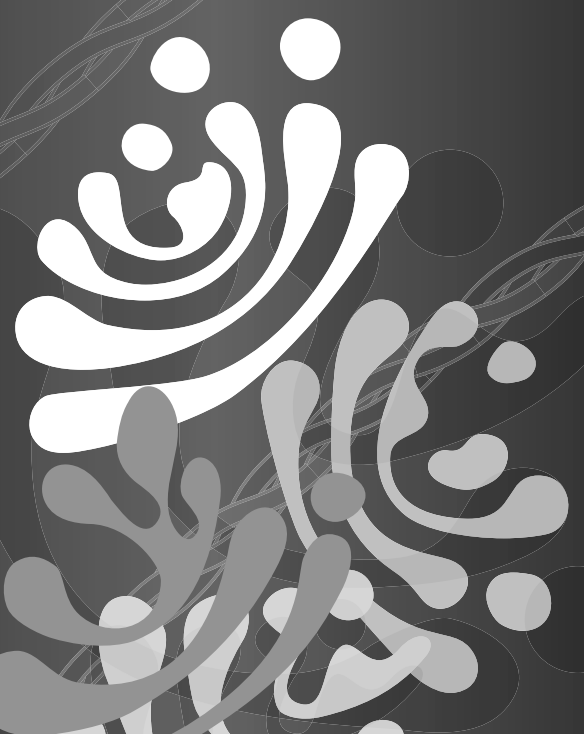

\section{(1)}

\section{CONCURRENT SESSIONS}

covering the entire range of

the molecular life sciences

\begin{tabular}{ll}
\hline Abstract submission & 12 June \\
\hline Early registration & 12 June \\
\hline On-line registration & 4 September
\end{tabular}

[e. www.the-embo-meeting.org

the.embo.meeting@embo.org 


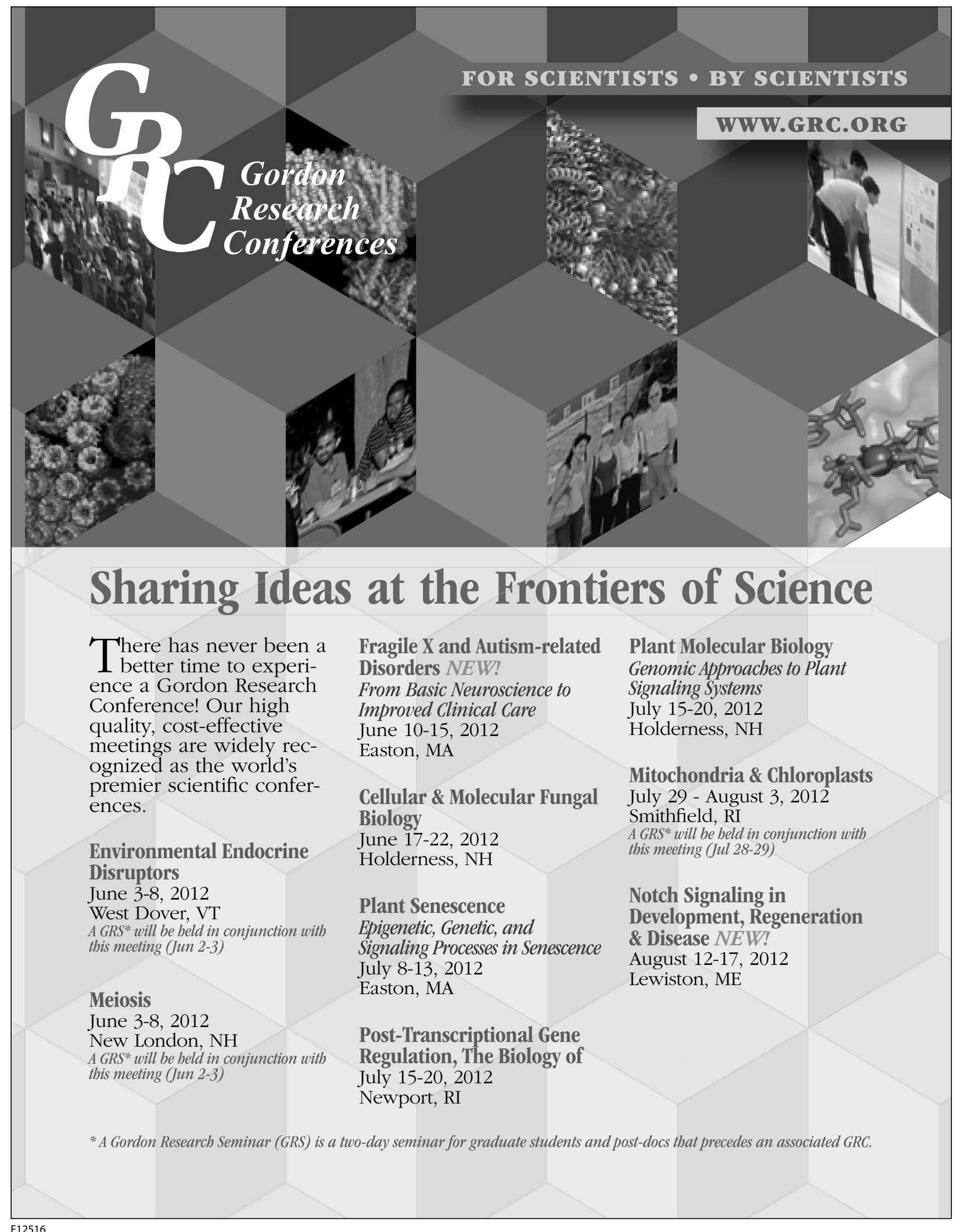




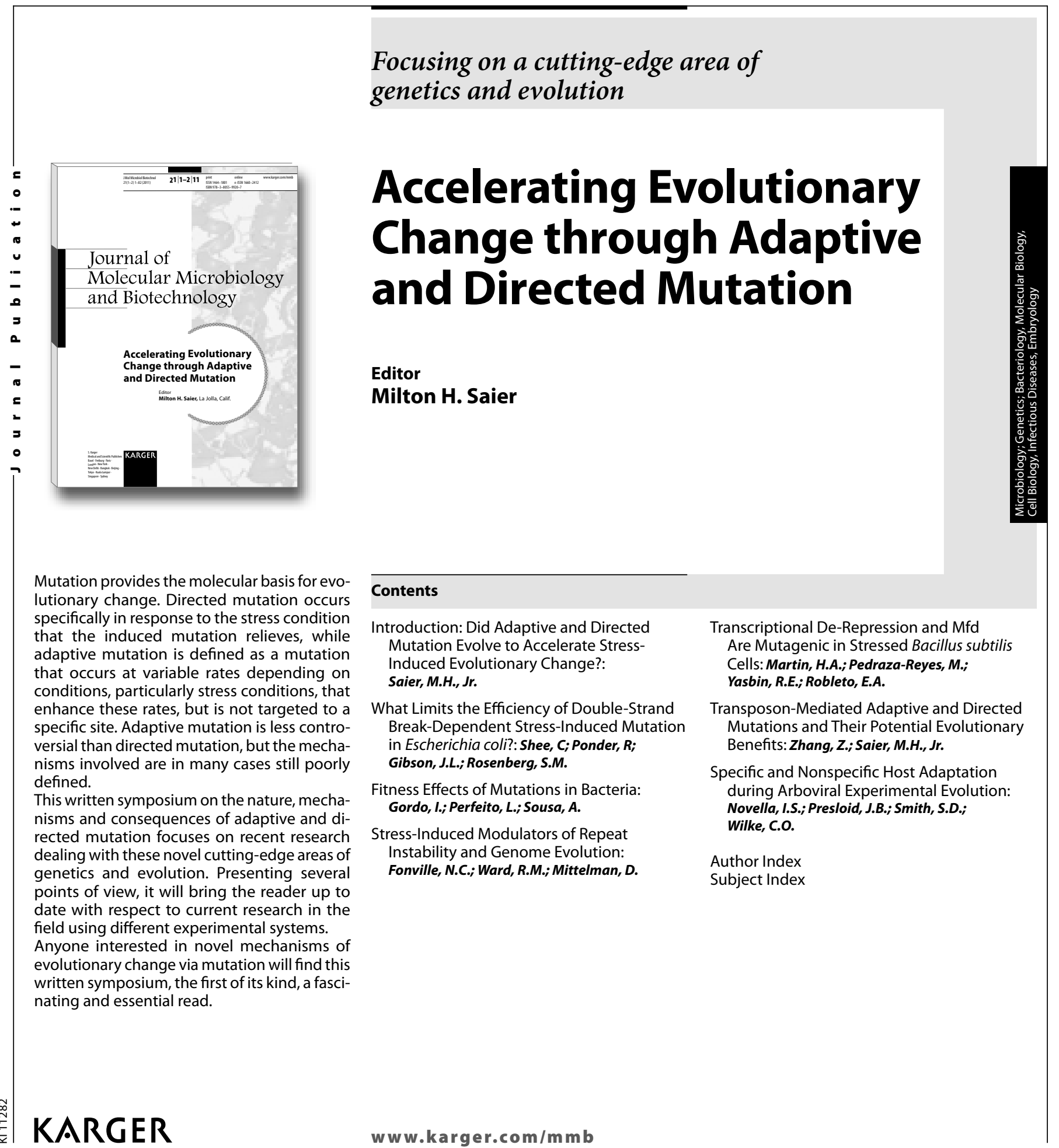

Accelerating Evolutionary Change through Adaptive and Directed Mutation Editor: Saier, M.H. (La Jolla, Calif.)

Editor: Saier, M.H. (La Jolla, Calif.)
82 p., 23 fig., 4 in color, 7 tab., soft cover, 2012

82 p., 23 fig., 4 in color, 7 tab., soft
CHF 39.- / EUR 33.- / USD 46.00

Prices subject to change

EUR price for Germany, USD price for USA only

ISBN 978-3-8055-9920-7

e-ISBN 978-3-8055-9921-4

Special Topic Issue:

Journal of Molecular Microbiology and

Biotechnology

Vol. 21, No. 1-2 (2011)

Included in subscription

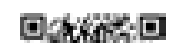

www.karger.com/m mb ranscriptional De-Repression and Mfd Pedraza-Reyes, $M$

ransposon-Mediated Adaptive and Directed Mutations and Their Potential Evolutionary

pecific and Nonspecific Host Adaptation during Arboviral Experimental Evolution: Novella, I.S.; Presloid, J.B.; Smith, S.D.;

Author Index Subject Index

\section{$\longrightarrow$ Please send: __ copy/ies}

Postage and handling free with prepayment

Payment

Please charge to my credit card

- $\square$ American Express $\square$ Diners

ᄂ $\square$ MasterCard $\square$ Visa

Card No.

ข

ర Exp.date

- CVV/CVC

( 3 digits in the signature field on the back of Visa and MasterCard)

$\square$ Check enclosed $\square$ Please bill me

Orders may be placed with any bookshop, subscription agency, directly with the publisher or through a Karger distributor.
Fax: +41 613061234

S. Karger AG, P.O. Box, CH-4009 Basel (Switzerland)

E-Mail orders@karger.ch, www.karger.com

Name/Address:

Date: 


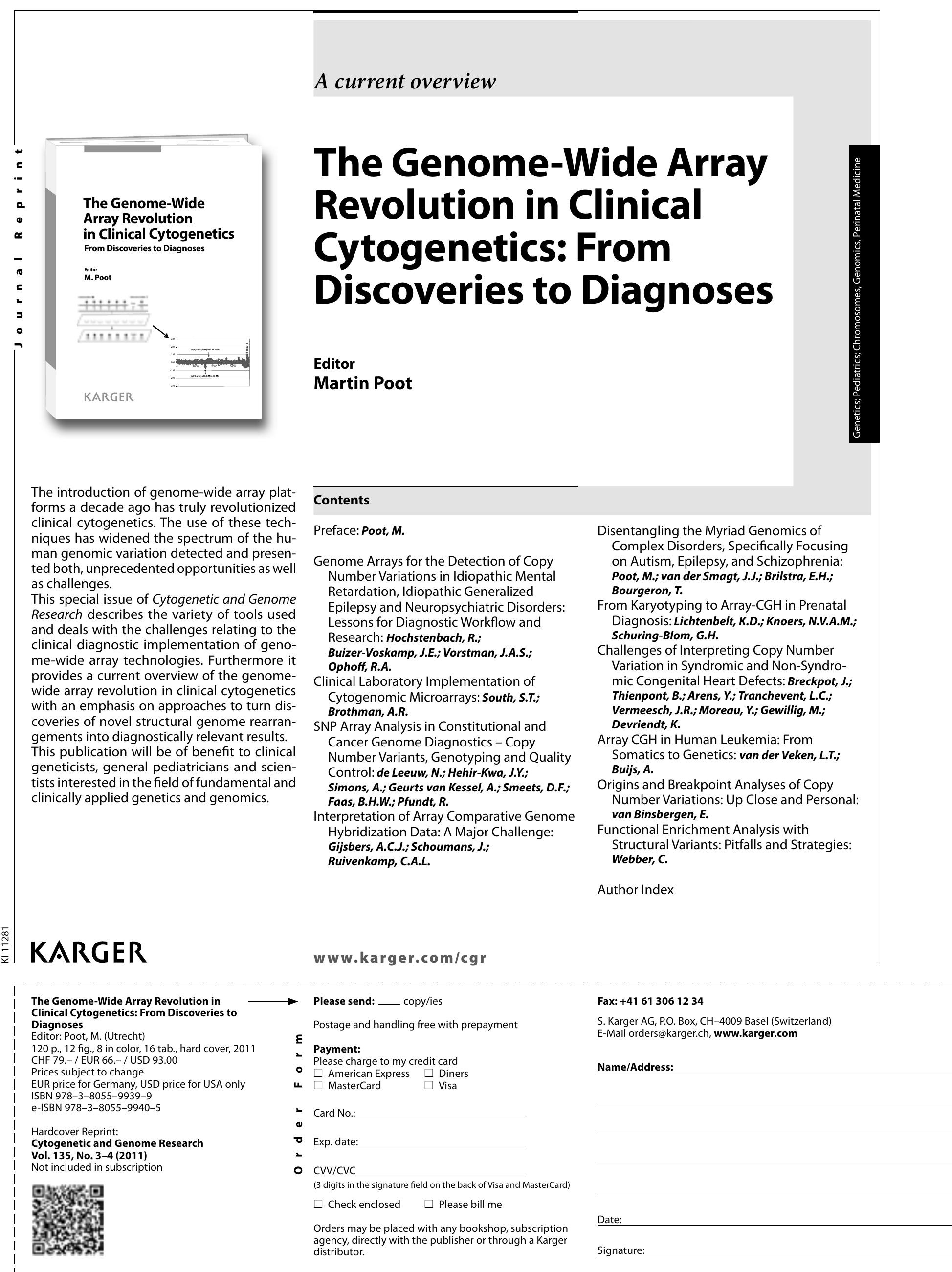




\section{Human Heredity}

International Journal of Human and Medical Genetics

Editor

M. Devoto, Philadelphia, Pa./

Rome

Senior Editor

D. Gordon, Piscataway, N.J.

Editorial Administrator

K. Montague, New York, N.Y.

\section{Associate Editors}

D.B. Allison, Birmingham, Ala.

G. Barbujani, Ferrara

M. Boehnke, Ann Arbor, Mich.

L. Brzustowicz,

Piscataway, N.J.

M. de Andrade,

Rochester, Minn.

F. Dudbridge, London

\section{E. Génin, Paris}

S.E. Hodge, New York, N.Y.

M. Knapp, Bonn

C. Lewis, London

Y.-Y. Teo, Singapore

H.K. Tiwari, Birmingham, Ala.

V. Vieland, Columbus, Ohio

E. Zeggini, Cambridge
Impact Factor: 2.337

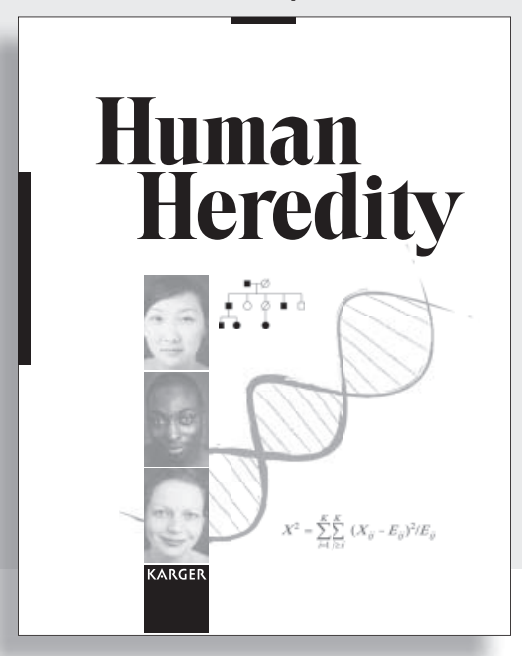

Gathering original research reports and short communications from all over the world, Human Heredity is devoted to methodological and applied research on the genetics of human populations, association and linkage analysis, genetic mechanisms of disease, and new methods for statistical genetics, for example, analysis of rare variants and results from next generation sequencing. The value of this information to many branches of medicine is shown by the number of citations the journal receives in fields ranging from immunology and hematology to epidemiology and public health planning, and the fact that at least $50 \%$ of all $\mathrm{Hu}$ man Heredity papers are still cited more than 8 years after publication (according to ISI Journal Citation Reports).

\section{Selected contributions}

Genome-Wide Meta-Analysis of Joint Tests for Genetic and Gene-Environment Interaction Effects: Aschard, H. (Boston, Mass.); Hancock, D.B.; London, S.J. (Triangle Park, N.C.); Kraft, P. (Boston, Mass.)

Simulating Sequences of the Human Genome with Rare Variants: Peng, B.; Liu, X. (Houston, Tex.)

The Meaning of Interaction: Wang, X.; Elston, R.C.; Zhu, X. (Cleveland, Ohio)

Effect Size Measures in Genetic Association Studies and Age-Conditional Risk Prediction: So, H.-C.; Sham, P.C. (Hong Kong)

Fast and Robust Association Tests for Untyped SNPS in Case-Control Studies: Allen, A.S. (Durham, N.C.); Satten, G.A. (Atlanta, Ga.); Bray, S.L. (Cambridge); Dudbridge, F. (Cambridge/London); Epstein, M.P. (Atlanta, Ga.)

A Data-Adaptive Sum Test for Disease Association with Multiple Common or Rare Variants: Han, F.; Pan, W. (Minneapolis, Minn.)

Testing Haplotype-Environment Interactions Using Case-Parent Triads: Shi, M.; Umbach, D.M.; Weinberg, C.R. (Research Triangle Park, N.C.)

Approaches for Evaluating Rare Polymorphisms in Genetic Association Studies: Li, Q. (Beijing); Zhang, H.; Yu, K. (Bethesda, Md.)
More information at

www.karger.com/hhe

- Pay-per-View and Subscriber Access to Full Text

- Full Table of Contents

- Full Editorial Board

- Free Abstracts and Selected Articles

- Online Sample Issue

- Submission/Guidelines for Authors

- Subscription Details

- Free Alert Service

- Online Library Recommendation

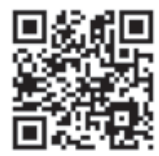

Human Heredity 2012: Volumes 73, 74 4 issues per volume Language: English ISSN 0001-5652 (print) ISSN 1423-0062 (online)

Listed in bibliographic services, including Current Contents ${ }^{\circledR} /$ Life Sciences, MEDLINE, Biological Abstracts, EMBASE/Excerpta Medica 


\section{Cytogenetic and Genome Research}

\section{Original Articles}

180 Unique Genomic Structure and Distinct Mitotic Behavior of Ring Chromosome 21 in Two Unrelated Cases Zhang, H.Z.; Xu, F.; Seashore, M.; Li, P. (New Haven, Conn.)

188 Molecular Insights into X;BTA5 Chromosome Rearrangements in the Tribe Antilopini (Bovidae) Cernohorska, H.; Kubickova, S. (Brno); Vahala, J. (Dvur Kralove n. L.); Rubes, J. (Brno)

199 A Comparative Analysis of the Mole Vole Sibling Species Ellobius tancrei and E. talpinus (Cricetidae, Rodentia) through Chromosome Painting and Examination of Synaptonemal Complex Structures in Hybrids Bakloushinskaya, I.Yu.; Matveevsky, S.N. (Moscow); Romanenko, S.A.; Serdukova, N.A. (Novosibirsk); Kolomiets, O.L.; Spangenberg, V.E.; Lyapunova, E.A. (Moscow); Graphodatsky, A.S. (Novosibirsk)

208 Chromosome Analysis of 82 Species of Scarabaeoidea (Coleoptera), with Special Focus on NOR Localization Dutrillaux, A.-M.; Dutrillaux, B. (Paris)

220 Development and Application of EST-Based Markers Specific for Chromosome Arms of Rye (Secale cereale L.) Xu, H.; Yin, D. (Shijiazhuang); Li, L.; Wang, Q.; Li, X.; Yang, X.; Liu, W. (Beijing); An, D. (Shijiazhuang)

\section{Short Reports}

163 Five Novel Locations of Neocentromeres in Human: 18q22.1, Xq27.1 27.2, Acro p13, Acro p12, and Heterochromatin of Unknown Origin

Klein, E. (Jena); Rocchi, M. (Bari); Ovens-Raeder, A. (München); Kosyakova, N.; Weise, A.; Ziegler, M. (Jena); Meins, M.; Morlot, S.; Fischer, W. (Hannover); Volleth, M. (Magdeburg); Polityko, A. (Minsk); Ogilvie, C.M. (London); Kraus, C. (Erlangen); Liehr, T. (Jena)
167 De novo Deletion of 1q31.1-q32.1 in a Patient with Developmental Delay and Behavioral Disorders

Milani, D.; Bedeschi, M.F. (Milano); Iascone, M. (Bergamo); Chiarelli, G.; Cerutti, M.; Menni, F. (Milano)

171 A Prevalent Y;15 Translocation in the Ethiopian Beta Israel Community in Israel

Chen-Shtoyerman, R.; Josefsberg Ben-Yehoshua, S.; Nissani, R.; Rosensaft, J.; Appelman, Z. (Rehovot/Jerusalem)

175 Chromosome Painting of the Pygmy Tree Shrew Shows that No Derived Cytogenetic Traits Link Primates and Scandentia

Dumas, F. (Palermo); Houck, M.L. (Escondido, Calif.); Bigoni, F. (Florence); Perelman, P. (Frederick, Md./Novosibirsk); Romanenko, S.A. (Novosibirsk); Stanyon, R. (Florence)

\section{Case Report}

229 Phenotypic and Molecular Characterization of Partial Trisomy 2q Resulting from Insertion-Duplication in Chromosome 18q: A Case Report and Review of Literature

Ponnala, R.; Ranganath, P.; Dutta, U.R.; Pidugu, V.K.; Dalal, A.B. (Hyderabad)

\section{Commentary}

235 Correction of the Wrong Name of a Fragile Site Associated to the DMD Gene Pelliccia, F.; Rocchi, A. (Roma) 